\title{
Diagnosis and management of chronic compartment syndromes: a review of the literature
}

\author{
Michael Barnes
}

Compartment syndromes may be acute or chronic. Acute syndromes may complicate fracture, soft tissue trauma, burns, and drug overdose. Very rarely is excessive exercise the underlying cause. ${ }^{1-5}$ Sportsmen and women (particularly footballers) are perhaps more prone to this condition than the general population because of the high incidence of tibial fractures. Acute compartment syndromes are a potentially limb threatening problem that should be dealt with urgently and hence are more in the remit of orthopaedic and accident and emergency departments than of sports medicine.

Chronic compartment syndromes are the definitive sports injury, being almost entirely due to exercise and overuse. Diagnosis and management are still a matter of debate and uncertainty.

\section{Historical aspects}

The first case of a genuine chronic compartment syndrome was documented by Mavor in $1956^{6}$ as a case report of a professional footballer with bilateral lower leg pain caused by exercise. All earlier reports of exercise related compartment syndromes had been acute syndromes induced by exercise, mostly in military recruits. ${ }^{7-13}$ It is interesting to note that the clinical description and treatment in Mavors' paper are very similar to current opinions and practice.

In the same volume of the journal, an editorial by Griffith ${ }^{14}$ cast doubt on Mavor's case and questioned the existence of a chronic compartment syndrome. However, over the past 40 years there have been well over 1000 documented cases (mostly confirmed by intracompartmental pressure measurement and the successful outcome of fasciotomy), so it would seem that Griffiths was wrong, and chronic compartment syndrome is now a well recognised specific condition, with its own history, symptoms, and treatment.

The correlation of the history and symptoms with raised intracompartmental pressure was first carried out by French and Price in $1962^{15}$ using the needle method of Wells et al. ${ }^{16}$

When Reneman ${ }^{17}$ published his series of 61 patients in 1975 , there had been only nine previously reported cases. All 70 cases were anterior/lateral. A chronic compartment syndrome of the deep posterior compartment had been suggested by Puranen ${ }^{18}$ in 1974 , but not confirmed by pressure measurements until $1981 .^{19}$ Even today there is still uncertainty about the causes of exercise related pain in and around the deep posterior compartment.

\section{Definition}

In the broadest and simplest terms a chronic compartment syndrome is defined as a condition of pain on exercise that is relieved by rest. Over months the symptoms become worse with progressively earlier onset. However, this definition could cover several other conditions. Hence the need for measurements of intracompartmental pressure.

\section{Anatomy}

Some $95 \%$ of chronic compartment syndromes occur in the lower leg. This is due to its particular anatomy and that intensive exercise of the lower leg is part of virtually all sports. The remaining 5\% are distributed between the forearm, ${ }^{2021}$ thigh, ${ }^{223}$ hands, ${ }^{24}$ and, very rarely, feet. ${ }^{25} 26$ What follows, therefore, will be limited to the lower leg.

It is a generally accepted view that there are four compartments in the lower leg; an anterior, deep posterior, lateral, and superficial posterior. Chronic compartment syndromes have been diagnosed in all four, but it is predominantly the anterior and deep posterior compartments that are most often involved. This is not a universally held belief. Davey et $a l^{27}$ suggested that the tibialis posterior muscle constitutes a separate compartment making a total of five compartments altogether. Detmer et $a l^{8}$ has taken this even further, stating that each muscle should be regarded individually. They also describe seven functional compartments: in addition to the anterior and lateral compartments, the deep posterior should be divided into proximal and distal, and the superficial posterior should be subdivided into distal, lateral, and medial. No work has been done to confirm that these are discrete pressure units. These additional subdivisions may be relevant for correct surgical decompression.

\section{Clinical aspects}

Many chronic compartment syndromes can be diagnosed by history alone. The patient complains of pain on exercise that is relieved by rest and has progressively worsened over a period of months. The pain may be localised to a specific compartment or described as a general ache. There may be distal neurological signs of paraesthesia in the foot. There are, however, several other conditions which may mimic these symptoms - for example, popliteal entrapment syndrome, medial tibial syndrome, or stress fracture. Most of these may be eliminated by other signs or routine investigations. Medial tibial syndrome always has associated inner border tibial tenderness; stress fractures can usually be confirmed by plain radiographs 
Table 1 Reported incidence of muscle hernias

\begin{tabular}{|c|c|c|c|}
\hline Authors & Year & $\begin{array}{l}\text { No of } \\
\text { Patients }\end{array}$ & Incidence (\%) \\
\hline Mavor $^{6}$ & 1956 & 1 & 100 \\
\hline French and Price ${ }^{15}$ & 1962 & 2 & 100 \\
\hline $\operatorname{Reneman}^{17}$ & 1975 & 61 & 60 \\
\hline Sudmann ${ }^{29}$ & 1979 & 51 & Not mentioned \\
\hline \multicolumn{4}{|l|}{ Puranen and } \\
\hline Alavaikko $^{19}$ & 1981 & 10 & Not mentioned \\
\hline McDermott et $a l^{30}$ & 1982 & 9 & 45 \\
\hline Qvarfordt $e t a l^{\beta 1}$ & 1983 & 108 & 40 \\
\hline Martens et $a^{\beta 2}$ & 1984 & 29 & 30 \\
\hline \multicolumn{4}{|l|}{ Wallensten and } \\
\hline Eriksson $^{33}$ & 1984 & 12 & Not mentioned \\
\hline Detmer et $a l^{8}$ & 1985 & 50 & Occasional \\
\hline Styf and Korner ${ }^{34}$ & 1986 & 80 & See.text \\
\hline Allen and Barnes ${ }^{35}$ & 1986 & 110 & None found \\
\hline Fronek et $a l^{\beta 6}$ & 1987 & 18 & $\begin{array}{l}39 \text { ( }<5 \text { in normal } \\
\text { subjects) }\end{array}$ \\
\hline Turnispeed $e t a l^{\beta 7}$ & 1989 & 209 & Not mentioned \\
\hline Pedowitz et $a l^{8}$ & 1990 & 131 & $\begin{array}{l}45.9 \text { ( } 12.9 \text { in normal } \\
\text { subjects) }\end{array}$ \\
\hline \multicolumn{4}{|l|}{ Ambramowitz and } \\
\hline Schepsis ${ }^{39}$ & 1994 & 28 & 25 \\
\hline
\end{tabular}

and popliteal entrapment syndrome will affect foot pulses (chronic compartment syndrome never affects the major vessels). However, none of these conditions are mutually exclusive, so the confirmation of one does not necessarily rule out the existence of the others.

On examination there is little or nothing to see. Some authors suggest that swelling over the anterior compartment can be felt in some patients, particularly after exercise. This is a subjective finding and gives no indication as to what might be happening in the deep posterior compartment. Swelling is of course, no indication of raised compartmental pressure. It is common to find grossly swollen and tense limbs with normal intracompartmental pressures (in patients with suspected acute compartment syndrome).

\section{Incidence of muscle hernias}

Muscle hernias may occur in association with anterior compartment syndrome (table 1). Some authors do not even mention themothers say that they are an occasional finding, others that they are a confirming diagnostic indicator.

In an earlier series of 110 consecutive patients $^{35}$ we found no muscle hernias. In the 10 years since, we have seen well over 1000 patients with suspected compartment syndrome and only 20 muscle hernias (an incidence $<1 \%$ ) and these have been equally distributed between patients with and without raised compartmental pressures. It has been argued that a muscle hernia is a strong indicator of a longstanding compartment syndrome as the increased pressure within the compartment has caused the fascial defect. ${ }^{31}$ It has also been suggested that the existence of a fascial defect will prevent the build up of pressure ${ }^{1417}$ implying that they should be a contraindication for increased pressure. Styf and Korner ${ }^{34}$ found muscle hernias in five out of 19 patients with confirmed anterior compartment syndrome on clinical examination, but then found a further 12 in 30 limbs undergoing surgery. The differences in the frequency of muscle hernias between normal subjects and patients with
Table 2 Evolution of chronic compartment syndrome pressure measurement techniques

\begin{tabular}{|c|c|c|}
\hline Authors & Year & Technique \\
\hline French and Price ${ }^{15}$ & 1962 & Wells et al ${ }^{16}$ needle \\
\hline Reneman $^{17}$ & 1975 & Needle \\
\hline Mubarak et al ${ }^{40}$ & 1976 & Wick \\
\hline D'Ambrosia $e t a l^{41}$ & 1977 & Needle with transducer \\
\hline Sudmann ${ }^{29}$ & 1979 & Needle and wick \\
\hline Rorabeck et $a l^{42}$ & 1980 & Slit \\
\hline Puranen and Alavaikko ${ }^{19}$ & 1981 & Wick \\
\hline Mubarak et $a l^{43}$ & 1981 & Slit \\
\hline McDermott et a ${ }^{30}$ & 1982 & STIC \\
\hline Raether and Lutter ${ }^{23}$ & 1982 & Whitesides $e t a l^{44}$ needle \\
\hline Christenson et al ${ }^{45}$ & 1983 & Epidural catheters \\
\hline Qvarfordt $e t a l^{46}$ & 1983 & Wick \\
\hline Rydholm et $a l^{47}$ & 1983 & Wick \\
\hline Wallensten $^{48}$ & 1983 & Wick \\
\hline Martens et $a l^{32}$ & 1984 & Wick \\
\hline Detmer et $a l^{28}$ & 1985 & Needle and wick \\
\hline Styf and Korner ${ }^{49}$ & 1986 & Microcapillary infusion \\
\hline Kutz et al ${ }^{20}$ & 1985 & Slit \\
\hline Allen and Barnes ${ }^{21}$ & 1986 & Slit \\
\hline Bell $^{50}$ & 1986 & Wick and slit \\
\hline Fronek et $a l^{36}$ & 1987 & Wick and slit \\
\hline Turnispeed $e t a l^{77}$ & 1989 & Stryker \\
\hline Pedowitz et $a l^{\beta 8}$ & 1990 & Slit \\
\hline
\end{tabular}

compartment syndrome found by Pedowitz et $a{ }^{\beta}$ were reported as significant.

The only conclusion that can be drawn from such a diversity of findings is that preselection of patients may influence the results when comparing series.

\section{Pressure measurement}

Measurement of intracompartmental pressure is required to confirm the diagnosis and establish exactly which compartments are involved. The techniques and equipment used have evolved over time (table 2). The needle and manometer techniques of Wells et $a l^{16}$ and Whitesides et $a l^{44}$ have largely given way to wick or slit catheters and pressure transducers. These more recent methods are not necessarily more accurate, but are much easier to use and more versatile. With flexible catheters and transducers the patient can exercise with the catheters in place, thus making it possible to measure pressure during exercise and immediately afterwards. This is obviously better than inserting a needle after exercise because of the time delay involved and the possibility that the localised trauma may give a falsely high pressure. Also, by using transducers and amplifiers an electrical signal is produced enabling a record of the fluctuations in pressure to be made.

Today most people use the slit catheter as it is readily available (or simple to make) and reliable with an adequate frequency response for measuring pressure during exercise. The older method of needle and manometer is rarely used, but does have the advantage of needing no specialised equipment so it can be used almost anywhere. The STIC (solid state transducer intracompartmental catheter) of McDermott $e t a l^{30}$ and the microcapillary infusion technique of Styf and Korner ${ }^{49}$ are both more complex methods designed to improve frequency response, but are both rather complicated for routine clinical use. The Stryker box is a simple hand held device containing a transducer, amplifier, and display, that con- 
Table 3 Diagnostic criteria of intracompartmental pressure measurement

\begin{tabular}{|c|c|c|}
\hline Authors & Year & Diagnostically relevant pressure values \\
\hline French and Price ${ }^{15}$ & 1962 & $\begin{array}{l}\text { Postexercise fall time }<30 \mathrm{~min} \text { in normal subjects, } \\
>100 \mathrm{~min} \text { in patients }\end{array}$ \\
\hline Reneman $^{17}$ & 1975 & $\begin{array}{l}\text { At six minutes postexercise pressure }>15 \mathrm{~cm} \mathrm{H}_{2} \mathrm{O}(11 \\
\mathrm{mm} \mathrm{Hg} \text { ) above resting pressure }\end{array}$ \\
\hline Puranen $^{19}$ & 1981 & $\begin{array}{l}\text { Mean pressure of } 50 \mathrm{~mm} \mathrm{Hg} \text { during running. Resting } \\
\text { of no value, but did observe slow postexercise fall }\end{array}$ \\
\hline McDermott $^{30}$ & 1982 & Mean pressure of $85 \mathrm{~mm} \mathrm{Hg}$ during running \\
\hline Mubarak and Hargens ${ }^{51}$ & 1982 & $\begin{array}{l}\text { Resting pressure }>15 \mathrm{~mm} \mathrm{Hg} \text {. Exercise pressure }>75 \\
\mathrm{~mm} \mathrm{Hg} \text {. Pressure remains }>30 \mathrm{~mm} \mathrm{Hg} \text { for }>5 \mathrm{~min} \text { after } \\
\text { exercise }\end{array}$ \\
\hline Qvarfordt $e t a l^{11}$ & 1983 & $\begin{array}{l}\text { Pressures raised before, during, and after exercise. } \\
\text { Postexercise decline } 40 \mathrm{~min} . \mathrm{T}_{\frac{1}{2}} 6 \mathrm{~min}\end{array}$ \\
\hline Wallensten ${ }^{48}$ & 1983 & $\begin{array}{l}\text { No difference at rest, still raised } 10 \mathrm{~min} \text { postexercise } \\
\text { (anterior), returned to normal }<10 \mathrm{~min} \text { (deep posterior) }\end{array}$ \\
\hline Detmer et $a l^{8}$ & 1985 & At rest, normal pressure $<15 \mathrm{~mm} \mathrm{Hg}$ \\
\hline Styf and Korner ${ }^{49}$ & 1986 & Muscle relaxation pressure \\
\hline Styf and Korner ${ }^{34}$ & 1986 & $\begin{array}{l}\text { Postexercise pressure }>35 \mathrm{~mm} \mathrm{Hg} \text { remained raised for }>6 \\
\text { min (Also muscle relaxation pressure was raised during } \\
\text { exercise. }>20 \text { mins to return to normal) }\end{array}$ \\
\hline Allen and Barnes ${ }^{35}$ & 1986 & $\begin{array}{l}\text { Exercise pressure }>50 \mathrm{~mm} \mathrm{Hg} \text { anterior, }>40 \mathrm{~mm} \mathrm{Hg} \text { deep } \\
\text { posterior No difference in resting pressures }\end{array}$ \\
\hline Fronek et $a l^{\beta 6}$ & 1987 & $\begin{array}{l}\text { Resting pressure } \geq 10 \mathrm{~mm} \mathrm{Hg} \text { and/or } \geq 25 \mathrm{~mm} \mathrm{Hg} 5 \mathrm{~min} \\
\text { after exercise }\end{array}$ \\
\hline Rorabeck et $a P^{2}$ & 1988 & $\begin{array}{l}\text { Pre-exercise pressure }>10 \mathrm{~mm} \mathrm{Hg} \text { and postexercise } \\
>15 \mathrm{~mm} \mathrm{Hg} \text { for }>15 \mathrm{~min}\end{array}$ \\
\hline Styf $\mathrm{f}^{3}$ & 1988 & $\begin{array}{l}\text { Relaxation pressure }>35 \mathrm{~mm} \mathrm{Hg} \text {, resting pressure }>30 \\
\mathrm{~mm} \mathrm{Hg} \text {, postexercise return to normal }>6 \mathrm{~min}\end{array}$ \\
\hline Turnispeed et $a \beta^{7}$ & 1989 & $\begin{array}{l}>20 \mathrm{~mm} \mathrm{Hg} \text { at rest (postexercise increase and slow } \\
\text { decline }>10 \mathrm{~min} \text { ) }\end{array}$ \\
\hline Pedowitz et al ${ }^{88}$ & 1990 & $\begin{array}{l}\text { Pre-exercise pressure } \geq 15 \mathrm{~mm} \mathrm{Hg} \text {, or postexercise } \\
\text { pressure } \geq 30 \mathrm{~mm} \mathrm{Hg} \text { at } 1 \mathrm{~min} \text { or } \geq 20 \mathrm{~mm} \mathrm{Hg} \text { at } 5 \mathrm{~min}\end{array}$ \\
\hline
\end{tabular}

nects directly to a needle or slit catheter. It was primarily designed for acute work, but it provides a practical compromise between the cheap and simple techniques and the more sophisticated and expensive ones.

\section{Diagnosis by pressure measurement}

Much has been written about the advantages and disadvantages of each particular method in regard to frequency response, reliability, reproducibility, accuracy, and cost. But the major area of debate and point of greatest clinical importance is the diagnostic pressure value and when and how should it be measured (table 3).

The first recorded pressure measurements of a patient with chronic compartment syndrome were by French and Price in 1962, ${ }^{15}$ who found that the major difference in the pressure recordings between patients with compartment syndrome and normal subjects was the time it took the pressure to return to its resting value after exercise. This method had to be adopted owing to the limitations in the technology available at the time-it would have been very difficult to measure the pressure during exercise with a needle technique. Since this first investigation the concept of postexercise pressure drop has largely remained the same and is still the most widely used diagnostic criterion. However, each new investigator has altered or adapted the figures slightly, changing either the time, the pressure value, or both.

The physiological justification for this method may be based on the $20 \%$ increase in muscle volume that occurs during exercise. ${ }^{54}$ Patients are usually exercised until the onset of symptoms, which may take many minutes. The volume increase during this period then takes time to disperse, so the pressure remains raised for some time after the cessation of exercise.
Other authors have used different concepts. Puranen and Alavaikko ${ }^{19}$ adopted a mean value of $50 \mathrm{~mm} \mathrm{Hg}$ during running and this figure was also used by Allen and Barnes. ${ }^{21}$ McDermott $e t$ al ${ }^{30}$ used a similar exercise protocol but adopted a higher threshold pressure of $85 \mathrm{~mm}$ $\mathrm{Hg}$. In addition they state that postexercise recordings are so variable that they should not be used for diagnosis. We agree with this statement, having found that the pressure drops immediately on the cessation of exercise. We think that a slow decline in postexercise pressure is more likely to be a blocked catheter rather than a finding of pathological relevance. The justification for using pressures recorded during exercise is that this is when the symptoms occur-the pain goes when the exercise stops.

During exercise, as the muscles contract and relax, a pulsatile pressure waveform is generated, with the maximum pressure corresponding to the contraction and the minimum pressure occurring during relaxation. Styf et a $l^{49556}$ considered the muscle relaxation pressure to be a more appropriate method of diagnosis than mean exercise pressure. This is based on the idea that if the exercise pressure drops below $30 \mathrm{~mm} \mathrm{Hg}$ during the relaxation phase of exercise the muscle can still be adequately perfused. Styf et al also found a good correlation between muscle relaxation pressure and postexercise fall, and dismissed mean exercise pressures as being unreliable, having found no significant differences between legs with and without compartment syndrome. This is explained by the effect of muscle contraction force on pressure.

The clinical relevance of pressures measured during exercise has been criticised on several grounds: the value being dependent on depth of catheter insertion and the strength of muscle contractions. Hargens $e t a \bar{l}^{7}$ found strong correlations between the pressure and the depth into the muscle and percentage maximum voluntary contraction (MVC). Higher pressures were recorded at greater depth and higher $\%$ MVC. This finding has been confirmed by Abramowitz and Schepsis. ${ }^{39}$

However, this work was done in the vastis medialis of the thigh which is anatomically very different from the muscles in the lower leg compartments. In addition it is possible to avoid these criticisms by inserting the catheters to a fixed depth and adopting a quantified exercise protocol.

Some have used the pre-exercise resting pressure for diagnosis (table 3), or at least taken it into account. ${ }^{2836-385153}$ However, as pointed out by Nkele $e t a t^{8}$ there is a range of nearly $20 \mathrm{~mm} \mathrm{Hg}$ in normal subjects, making any use of this figure questionable, and similarly Allen and Barnes ${ }^{35}$ found a wide variation in the resting pressures of patients with chronic compartment syndrome.

Hence there is no real consensus on definitive diagnostic values. This probably reflects the lack of understanding about the underlying pathophysiology.

However, intracompartmental pressure measurements remain the most direct and best 
objective method of diagnosis. Many other methods have been used in the investigation of chronic compartment syndrome, but these have largely been in an attempt to find out more about the underlying causes, rather than as practical diagnostic techniques.

\section{Other methods of investigation BONE SCANS}

Radioisotope imaging is a useful technique in the diagnosis of lower leg pain; in particular, bone scans are the best method to confirm stress fractures. Several authors ${ }^{18336}$ have attempted to use bone scanning to diagnose compartment syndrome, but the results have been inconclusive. This is not an appropriate technique for the diagnosis of chronic compartment syndrome, but is necessary for the elimination of other diseases.

METHOXY ISOBUTYL ISONITRILE

Methoxy isobutyl isonitrile has been used to image ischaemic heart muscle for some time. Recently, this technique has been applied to skeletal muscle in the hope that it can distinguish between normal and pathological compartments. ${ }^{5960}$ The disadvantages of this technique are that it subjects the patient to radiation, the radiopharmaceutical is very expensive, and it requires 3D imaging techniques. Should it prove to be reliable it has the advantage of being more widely available than pressure measurements and is less invasive.

\section{ELECTROPHYSIOLOGY}

There are two types of investigation that may be applied to chronic compartment syndrome. Electromyography (EMG) can be used to give an indication of the strength of muscle contractions, and hence may be useful in shedding light on the causes of compartment syndrome. Nerve conduction velocity (NCV) may show neurological changes due to raised intracompartmental pressure either directly exerting pressure on the nerves or affecting them by disrupting the blood supply. Both may be useful research tools, but it is rare for intracompartmental pressures to become sufficiently elevated that the nerves are affected, so the diagnostic use is limited.

MAGNETIC RESONANCE IMAGING

Magnetic resonance imaging (MRI) has been used to investigate chronic compartment syndromes. ${ }^{5961}$ It has the obvious advantages of being non-invasive, producing an image of all the compartments at the same time, and perhaps providing additional information as to the causes. At present it is still a very expensive diagnostic technique, and rather an indirect method of diagnosis.

\section{ULTRASOUND IMAGING}

Gershuni et $a l^{22}$ have used ultrasound to measure changes in the size of the anterior compartment after exercise. This has the advantages of being totally non-invasive and widely available, but is not really a valid diagnostic technique. It can only be used on the anterior compartment, and there is no evidence to suggest that an increase in the compartment volume is related to an increase in the compartment pressure. It could be argued that the compartment pressure increases because there is no increase in the compartment volume.

MUSCLE BLOOD FLOW

This technique has been used for many years. ${ }^{15}$ Styf et $a p^{5}$ correlated muscle relaxation pressure with muscle blood flow during exercise. Qvarfordt et $a l^{\beta 1}$ found that muscle blood flow decreased during exercise in patients with raised pressures. These findings may shed light on the underlying pathology, but are again more a research than clinical tool.

\section{Treatment}

DO NOTHING

The real incidence of chronic compartment syndromes in the population at large is unknown. This is because it is a self limiting condition, the pain occurs during exercise and goes with rest. Many potential patients will simply give up their activity rather than seek medical treatment. This attitude may unfortunately be adopted by some members of the medical profession who recommend that "if it hurts don't do it". Only a small percentage of potential patients may ever progress to reach a definitive diagnosis.

Many patients can trace the earliest symptoms back to an increase in or a change of activity. Reducing activity back to previous levels often prevents the pain, and some patients consider this to be the best option.

There is one potential danger with this method of treatment. There is a small amount of evidence to suggest that a chronic compartment syndrome may, under certain circumstances (excessive overuse), become acute and therefore potentially limb threatening. This can only be inferred from the very few cases of exercise induced acute compartment syndromes which sometimes list chronic symptoms in the history. ${ }^{173263}$ There is no direct evidence.

\section{CONSERVATIVE MEASURES}

Preventive

It is widely believed, although there can be no real objective scientific evidence, that inappropriate training may be a major contributing factor to the development of a chronic compartment syndrome. Such factors as incorrect or worn out footwear, running on hard surfaces, and changing or increasing activity have all been suggested as possible causes. There is also the suggestion that chronic compartment syndrome may be caused by biomechanical abnormalities ${ }^{64}$ and in particular excessive pronation. If this is the case then correcting the gait by the use of orthotics should prevent the symptoms. As yet this theory and the effectiveness of orthotics have neither been proved nor disproved.

\section{Curative}

As well as restricting activity to within comfortable limits, total rest has also been suggested as a treatment. It is our experience that 
rest has no effect at all on genuine cases. Even when patients do nothing more strenuous than everyday walking for several months, the symptoms return within days of recommencing to run. This contradicts the theory that muscle hypertrophy is a contributing factor, as muscle will waste very quickly with this level of inactivity.

Many other conservative treatments have been tried. Anti-inflammatory drugs, pain killers, ice, heat, ultrasound, physiotherapy, and steroid injections have all been used at some stage. Most of these treatments are effective at alleviating the symptoms to a degree, but they do not cure the underlying problem. In the series of 80 patients described by Styf and Korner $^{56}$ all had tried a range of conservative measures, including diuretics, without success. Martens et $a l^{\beta 2}$ treated nine patients conservatively with prolonged rest, physiotherapy, antiinflammatory drugs, and stretching exercise of the flexor muscles, but this could not be considered successful as all the patients had to reduce their sports activity to some extent Fronek et $a^{\beta 6}$ initially treated 18 patients conservatively with rest, stretching, and modification of activity. However, 13 of 18 found this unsatisfactory and went on to surgery. The remaining five did not improve, but continued to restrict their activity.

Hence all have found conservative measures to be unsuccessful.

\section{SURGERY}

It is generally accepted that surgery is the only really effective treatment for a chronic compartment syndrome. Various different fasciotomy techniques have been described, ${ }^{17} 2728343637485165$ but all have the same effect-to divide the restricting envelope of the fascia and thus effectively increase the size of the compartment.

The underlying cause of chronic compartment syndrome is still unknown. One of the possible causes may be due to changes in the mechanical properties of the fascia-for example, reduced compliance due to increased thickness. ${ }^{66}$ If, as seems most likely (as long term rest and all conservative measures are ineffective), these changes are irreversible, then surgery must be the only effective treatment.

\section{Outcomes}

The outcome of surgery is generally very good with some success rates reaching $100 \%$. A successful result can vary from an increased exercise tolerance to complete absence of symptoms. Several authors have also measured postoperative pressures for confirmation, ${ }^{192133} 34$ although these can be difficult to interpret owing to the presence of scar tissue. There are some poorer results, particularly with the deep posterior compartment. Ambramowitz and Schepsis ${ }^{39}$ found that all 16 patients who underwent anterior compartment fasciotomy had good results. However, only 13 out of 20 had satisfactory results in the deep posterior compartment. Similarly Rorabeck et $a l^{55}$ ob- tained complete success in the anterior compartment but in only 10 out of 12 with the deep posterior compartment. Both these authors suggest that the failures were due to incomplete fasciotomy, a theory supported by Puranen and Alavaikko ${ }^{19}$ who went on to redo his failures with more extensive surgery, obtaining successful outcomes.

In one of the largest series Turnispeed $e t a l^{37}$ decompressed 209 patients, 100 with a subcutaneous fasciotomy and 109 with the unusual method of open fasciectomy. The success rate was higher (98\%) with the open procedure than with the closed (89\%). However, no mention was made of recurrence rates in specific compartments.

The comparatively low success rate of surgery in the deep posterior compartment may result from several reasons. The possibility of incomplete fasciotomy has already been mentioned, and some authors are cautious about excessive dissection in an athlete, possibly leading to muscle weakness. A further reason may be incomplete decompression of the tibialis posterior, if as suggested by Davey $e t$ $a l^{7}$ it is a separate compartment. There is also the possibility of multiple diseases with similar presentations. Detmer ${ }^{67}$ has subdivided patients with exercise pain in the deep posterior compartment into three distinct groups, which are not all treatable by surgery and may well coexist.

POSTOPERATIVE MANAGEMENT

The successful outcome of surgery may also depend on the immediate postoperative management. The earliest possible mobilisation is required to maximise the effect of the fasciotomy. If the patient remains inactive in bed for several days after surgery, then the fascia may well heal back to its original size and make the surgery ineffective.

Rorabeck et $a t^{55}$ encouraged patients to walk as much as possible on the first postoperative day; Bell ${ }^{50}$ kept his patients in bed for five days, but encouraged them to perform active foot dorsiflexion one day after surgery; Detmer et al ${ }^{28}$ kept the legs raised for 48 to 72 hours to reduce oedema and hence speed recovery, whereas Wallensten ${ }^{48}$ allowed his patients to walk immediately after surgery.

Styf and Korner ${ }^{34}$ kept the patient's legs raised for 12 hours and then encouraged walking.

\section{COMPLICATIONS}

Some authors have admitted to surgical complications. Detmer et $a l^{28}$ in a series of 100 patients had a total of 11 . These included one arterial injury repair, five haematomas, four wound infections, three nerve injuries, and one deep venous thrombosis. Fronek et $a^{\beta 6}$ reported only one wound infection in a series of 18 patients. The published complication rates are not sufficiently high to consider that surgery may be too risky; but there are other possible contraindications which should be considered. 
POSSIBLE DETRIMENTAL EFFECTS OF SURGERY There is some speculation concerning the possible detrimental effects of surgery. As has already been mentioned there are concerns about excessive surgical dissection causing muscle weakness. Garfin et $a l^{88}$ found that muscle force decreased with fasciotomy, which may be a problem for athletes. This work was carried out on dogs so it only shows an immediate effect; there was no long term follow up. No measurements have been done to see if this is a genuine long term problem. A more recent study ${ }^{69}$ has shown that preoperatively patients with compartment syndrome have weaker muscles than normal subjects. Our current research shows that patients with chronic compartment syndrome have greater power but less endurance than normal subjects.

It is widely thought that fasciotomy is successful because it increases the size of the compartment, thereby increasing the volume and reducing the pressure generated by exercise. However, if the cause of increased pressure is stronger muscle contractions, then perhaps the effect of fasciotomy is to reduce the power of the contractions and thus to reduce the pressure. This theory correlates with the work of Hargens et al, ${ }^{57}$ who found that intracompartmental pressure was related to muscle contraction force.

\section{REPEAT SURGERY}

As mentioned earlier there have been some failures of surgery. Many of these have then been successfully treated by a second more extensive operation. It is important to distinguish between patients who have never had relief of symptoms and those who have had a recurrence months or even years later. Bell ${ }^{50}$ had five patients who still had symptoms and elevated pressures after fasciotomy. These were successfully treated by fasciectomy. In the series of Detmer et $a l^{28}$ of 100 patients undergoing surgery, five had had a recurrence of symptoms within two months. All five were then cured by a second operation. We have found a small but important group of patients who were free of symptoms for several years before the symptoms returned. These patients have also responded well to a second operation, but it is difficult to explain why the symptoms returned. This may cast doubt on the long term effects of fasciotomy. No comprehensive long term follow up studies have yet been done.

\section{Conclusion}

Chronic compartment syndrome of the lower leg is a relatively common sports injury. It is usually easy to confirm the diagnosis from history alone, but in more difficult cases, intracompartmental pressure measurement is required. The treatment of choice is fasciotomy, which has a very high success rate. Despite the abundance of literature on the subject over the past 40 years, there are still several areas of disagreement, principally that of an exact diagnostic pressure value. This may become clearer as more work is done to establish the underlying cause.

1 Tomkins DG. Exercise myopathy of the extensor carpi ulnaris muscle. F Bone foint Surg Am 1977;59A:407-8.

2 Bird C B, McCoy JW. Weight-lifting as a cause of compartment syndrome in the forearm. F Bone foint Surg Am 1983;65A:406.

3 Imbriglia JE, Boland DM. An exercise-induced compartment syndrome of the dorsal forearm. F Hand Surg? 1984; 9A:142-3.

4 Fleischman $\mathrm{AH}$. Ischemic necrosis of the tibialis anticus muscle with renal syndrome. Bull Hosp $f_{t}$ Dis 1961;22 $146-9$

5 Bidwell JP, Gibbons CER, Godsiff S. Acute compartment syndrome of the thigh after weight training. $\mathrm{Br} \mathcal{F}$ Sports Med 1996;30:264-5.

6 Mavor GE. The anterior tibial syndrome. $\mathcal{F}$ Bone foint Surg Br 1956;38B:513-17.

7 Sirbu A, Murphy MJ, White AS. Soft tissue complications of fractures of the leg. California and Western Medicine 1944; 60:53-6.

8 Blandy JP, Fuller R. March gangrene. Ischaemic myositis of the leg muscles from exercise. $f$ Bone foint Surg $\mathrm{Br}$ 1957;39B:679.

9 Horn CE. Acute ischaemia of the anterior tibial muscle and the long extensor muscles of the toes. $\mathcal{F}$ Bone foint Surg 1945:27;615-22.

10 Hughes JR. Ischaemic necrosis of the anterior tibial muscles due to fatigue. $\mathcal{F}$ Bone foint Surg $\mathrm{Br}$ 1948;30B:581-94.

11 Carter AB, Richards RL, Zachary RB. The anterior tibial syndrome, Lancet 1949;ii:928-34.

12 Tillotson JF, Coventry MB. Spontaneous ischemic necrosis of the anterior tibial muscle: report of a case. Proceedings of the Mayo Clinic 1950;25:223-7.

13 Kornstad L. Tibialis anterior syndrome. Nord Med 1955;53: 694.

14 Griffiths DL. The anterior tibial syndrome: a chronic form? f Bone foint Surg Br 1956;38B:438-39.

15 French EB, Price WH. Anterior tibial pain. BMF 1962;ii: 1290-96.

16 Wells HS, Youmans JB, Miller DG. Tissue pressure (intracutaneous, subcutaneous, and intramuscular) as related to venous pressure, capillary filtration, and other factors. F Clin Invest 1938;17:489-99.

17 Reneman RS. The anterior and the lateral compartmental syndrome of the leg due to intensive use of muscles. Clin Orthop 1975;113:69-80.

18 Puranen J. Medial tibial syndrome. Exercise ischaemia in the medial fascial compartment of the leg. $\mathcal{F}$ Bone foint Surg $\mathrm{Br}$ 1974;56B:712-15.

19 Puranen J, Alavaikko A. Intracompartmental pressure increase on exertion in patients with chronic compartment syndrome in the leg. F Bone foint Surg Am 1981;63A:1304309.

$20 \mathrm{Kutz}$ JE, Singer R, Lindsay M. Chronic exertional compartment syndrome of the forearm: a case report. $\mathcal{F}$ Hand Surg 1985;10A:302-304

21 Allen MJ, Barnes MR. Chronic compartment syndrome of the flexor muscles in the forearm: A case report. $\mathcal{F}$ Hand Surg '1989;14B:47-8.

22 Peltokallio P. The posterior compartment syndrome of the thigh. Proceedings of the World Congress of Sports Medicine, Vienna 1982;893-6.

23 Raether PM, Lutter LD. Recurrent compartment syndrome in the posterior thigh. Report of a case. Am $\mathcal{f}$ Sports Med 1982;10:40-42.

24 Phillips JH, Mackinnon SE, Murray J , Mcmurtry RY. Exercise-induced chronic compartment syndrome of the first dorsal interosseous muscle of the hand: A case report. f Hand Surg 1986;11A:124-27.

25 Middleton DK, Johnson JE, Davies JF. Exertional compartMiddleton DK, Johnson JE, Davies JF. Exertional compart-
ment syndrome of bilateral feet: a case report. Foot Ankle ment syndrome of

26 Lokiec F, Siev-ner I, Pritsch M. Chronic compartment syndrome of both feet. $\mathcal{F}$ Bone foint Surg 1991:73B;1 78-9.

27 Davey JR, Rorabeck CH, Fowler PJ. The tibialis posterio muscle compartment: an unrecognised cause of exertiona compartment syndrome. Am $\mathcal{F}$ Sports Med 1984;12:391-6.

28 Detmer D E, Sharpe K, Sufit R, Girdley F. Chronic compartment syndrome: diagnosis management and outcomes. Am $\mathcal{F}$ Sports Med 1985;13:162-70.

29 Sudmann E. The painful chronic anterior lower leg syndrome. A prospective clinical and experimental study. Acta Orthop Scand 1979;50:573-81

30 McDermott AGP, Marble AE, Yabsley RH, Phillips B. Monitoring dynamic anterior compartment pressures during exercise. A new technique using the STIC catheter. $A m$ $\mathcal{f}$ Sports Med 1982;10;83-89.

31 Qvarfordt P, Christenson JT, Eklof B, Ohlin P, Saltin B. Intramuscular pressure muscle blood flow and skeletal muscle metabolism in chronic anterior tibial compartmen syndrome. Clin Orthop 1983;179:284-90.

32 Martens MA, Backaert M, Vermaut G, Mulier JC. Chronic leg pain in athletes due to recurrent compartment syndrome. Am $\mathcal{F}$ Sports Med $1984 ; 12: 148-51$.

33 Wallensten R, Eriksson E. Intramuscular pressures in exercise induced lower leg pain. Int $f$ Sports Med 1984;5:31-5. 
34 Styf JR, Korner LM. Chronic anterior compartment syndrome of the leg. F Bone foint Surg Am 1986;68A:1338-47.

35 Allen MJ, Barnes MR. Exercise pain in the lower leg. Chronic compartment syndrome and medial tibial syndrome. F Bone foint Surg Br 1986;68B:818-23.

36 Fronek J, Mubarak SJ, Hargens A R, Lee Y F, Gershuni D $\mathrm{H}$, Garfin, et al. Management of chronic exertional anterior compartment syndrome of the lower extremity. Clin Orthop 1987;220:217-27.

37 Turnispeed W, Detmer DE, Girdley F. Chronic compartment syndrome: an unusual cause for claudication. Ann Surg 1989;210:557-63.

38 Pedowitz RA, Hargens AR, Mubarak SJ, Gershuni DH. Modified criteria for the objective diagnosis of chronic compartment syndrome of the leg. Am $\mathcal{F}$ Sports Med 1990 18:35-40.

39 Abramowitz AJ, Schepsis AA. Chronic exertional compartment syndrome of the lower leg. Orthopaedic Review 1994 23:219-26.

40 Mubarak SJ, Hargens AR, Owen CA, Garetto LP, Akeson WH. The wick catheter technique for measurement of intramuscular pressure. A new research and clinical tool. $\mathcal{f}$ intramuscular pressure. A new research

41 D'Ambrosia RD, Zelis RF, Chuinard RG, Wilmore J. Interstitial pressure measurements in the anterior and posterior compartments in athletes with shin splints. Am F Sports Med 1977;5:127-31.

42 Rorabeck CH, Castle GSP, Logan J, Hardy R. The slit catheter: a new device for measuring intracompartmental pressures. Surgical Forum Orthopaedic Surgery 1980;31: 513-15.

43 Mubarak SJ, Hargens AR, Lee YF, Lundblad AK, Castle GSP, Rorabeck CH. Slit catheter - a new technique for measuring tissue fluid pressure and quantifying muscle contraction. Transactions of the Orthopedic Research Society 1981;6:34.

44 Whitesides TE, Haney TC, Harada H, Holmes HE, Morimoto K. A simple method for tissue pressure Morimoto K. A simple method for tissue pressure

determination. Arch Surg 1975,110:1311-13.

Christenson J1, Eklof B, Wulf $\mathrm{K}$. The chronic compartment syndrome and response to diuretic treatment. Acta Chirurgica Scandinavica 1983;149:249-52.

46 Qvarfordt P, Christenson JT, Eklof B. Intramuscula pressure muscle blood flow and skeletal muscle metabolism in chronic anterior tibial compartment syndrome. Clin Orthop 1983;79:284-90.

47 Rydholm U, Werner CO, Ohlin P. Intracompartmental forearm pressure during rest and exercise. Clin Orthop 1983;175:213-15

48 Wallensten $R$. Results of fasciotomy in patients with medial tibial syndrome or chronic anterior compartment syndrome. F Bone foint Surg Am 1983;65A:1252-5.

49 Styf JR, Korner LM. Microcapillary imfusion technique for measurement of intramuscular pressure during exercise. Clin Orthop 1986;207:253-62.

50 Bell S. Repeat compartment decompression with partial fasciectomy. $\mathcal{F}$ Bone foint Surg Br 1986;68B:815-17.

51 Mubarak SJ, Hargens AR. Exertional compartment syndromes. In: Mack RP, ed. Symposium on the foot and leg in running sports. Missouri: American Academy of Orthopaedic Surgeons, 1982;141-59.
52 Rorabeck CH, Bourne RB, Fowler P, Finlay JB, Nott L. The role of tissue pressure measurement in diagnosing chronic role of tissue pressure measurement in diagnosing chronic 1988;16:143-6.

53 Styf J. Diagnosis of exercise-induced pain in the anterior aspect of the lower leg. Am F Sports Med 1988;16:165-9.

54 Wright S. Applied physiology. 10th ed. Oxford: Oxford University Press, 1961.

55 Styf JR, Korner LM, Suurkula M. Intramuscular pressure and muscle blood flow during exercise in chronic compartment syndrome. F Bone foint Surg $\mathrm{Br}$ 1987;69B 301-5.

56 Styf JR, Korner LM. Diagnosis of chroic anterior compartment syndrome in the lower leg. Acta Orthop Scand 1987; $58: 139-44$.

57 Hargens AR, Sejersted OM, Kardel KR, Blom P, Hermansen $\mathrm{L}$. Intramuscular fluid pressure: a function of conmansen L. Intramuscular fluid pressure: a function of conOrthopedic Research Society 1982:7:371.

58 Nkele C, Aindow J, Grant L. Study of pressure of the normal anterior tibial compartment in different age groups using the slit-catheter method. F Bone foint Surg Am 1988, 70A:98-101

59 Amendola A, Rorabeck CH, Vellett D, Vezina W, Rutt B, Nott $L$. The use of magnetic resonance imaging in exertional compartment syndromes. Am $\mathcal{f}$ Sports Med 1990;18:29-34.

60 Set PAK, Miles KA, Emmerson S, Jenner JR. Leg muscle scintigraphy with $99 \mathrm{Tcm}$ MIBI and single photon suspected compartment syndromes of the calf. British Institute of Radiology Congress 1994;38.

61 Fleckenstein JL, Shellock FG. Exertional muscle injuries: magnetic resonance imaging evaluation. Top Magn Reson Imaging 1991;3:50-70.

62 Gershuni DH, Gosink BB, Hargens AR, Gould RN, Forsythe JR, Mubarak SJ, et al. Ultrasound evaluation of the anterior musculofascial compartment of the leg following exercise. Clin Orthop 1982;167:185-90.

63 Leach RE, Hammond G, Stryker WS. Anterior tibial compartment syndrome acute and chronic. $\mathcal{F}$ Bone foint Surg Am 1967;49A:451-62.

64 Bates P. Shin splints - a literature review. Br $\mathcal{f}$ Sports Med 1985;19:132-7.

65 Rorabeck CH, Bourne RB, Fowler PJ. The surgical treatment of exertional compartment syndrome in athletes. F Bone foint Surg Am 1983;65A:1245-51.

66 Hurschler C, Vanderby R, Martinez DA, Vailas AC, Turnispeed WD. Mechanical and biochemical analyses of tibial compartment fascia in chronic compartment syndrome. Ann Biomed Eng 1994;22:272-9.

67 Detmer DE. Chronic shin splints: classification and management of medial tibial stress syndrome. Sports Med 1986;3:436-46.

68 Garfin SR, Tipton CM, Mubarak SJ, Woo LY, Hargens AR, Akeson WH. Role of fascia in maintenance of muscle tension and pressure. F Appl Physiol 1981;51:317-20.

69 Varelas FL, Wessel J, Clement DB, Doyle DL, Wiley JP. Muscle function in chronic compartment syndrome of the leg. F Orthop Sports Phys Ther 1993;18:586-89. 